\title{
Space-Based Assessment of the Compliance of Gsm Operators in Establishing Base Transceiver Station (Bts) In Nigeria Using Abuja Municipal Area Council as Case Study
}

\author{
Aderoju Olaide M, Godstime James, Olojo Olabamiji, Oyewumi Ademuyiwa, \\ Eta Joseph, Onuoha Hilda U, Salman Khalid, Nwadike Blessing K. \\ Department of Strategic Space Application, National Space Research and Development Agency (NASRDA), \\ Abuja, FCT, Nigeria.
}

\begin{abstract}
On the $16^{\text {th }}$ of May, 2001, the first Global System for Mobile Communications: originally called Groupe Spécial Mobile (GSM) call was made in Nigeria, thereby opening communication among the teaming population in the country. Given the mode of operation of GSM technology, Base Transceiver Stations (BTS) are required for the provision of GSM services. Consequently, network of base stations were established in areas that enjoyed the GSM services all over Nigeria. However, studies have shown that exposure to GSM radiations are linked to health hazards such as fatigue, headache, decreased concentration, dizziness, local irritation, tumour induction, sperm motility, morphology and viability, cancer, especially brain tumour and leukaemia, viral and infectious diseases. Given these potential health impacts of BTS on humans, the National Environmental Standards and Regulations Enforcement Agency (NESREA) established guidelines for National Environmental Standards for Telecommunications and Broadcasting Facilities. The guidelines provided for the establishment of BTS within a minimum setback of ten (10) meters from the perimeter wall (fence) of residential/business premises, schools and hospitals. Similarly, where there is no perimeter wall (fence), the BTS must be at a minimum of twelve (12) meters from the wall of residential/business premises schools and hospitals. Consequently, using spatial analysis techniques, this study examined compliance of GSM service providers with the established guidelines for the mounting of BTS within three Abuja districts in the Federal Capital Territory (FCT); namely, Utako, Garki and Wuse. All the 119 BTS sampled in the study failed the $10 \mathrm{~m}$ and $12 \mathrm{~m}$ buffer zone tests. As a result, policy prescription was made on the way forward.
\end{abstract}

Key Words: Base Transceiver Station (BTS), Electromagnetic Radiation (EMR), Groupe Spécial Mobile (GSM) Mast, Geographic Information system (GIS).

\section{Introduction}

With technology rapidly advancing, people living within close range of mobile phone base stations have become increasingly concerned over the potential harmful effects of radio frequency radiation produced by these devices to their health (Kwan-Hoong, 2003). Emerging evidence suggest there could be some very serious health implications, most notably an increased incidence of cancer for people working or residing in the vicinity of mobile phone base station transmitter masts. Several surveys have found a variety of self-reported symptoms for people who live close to base stations. Connor in 2005 stated that the United Kingdom has allowed the highest output of radiation in the world. She also emphasized that the United Kingdom recently adopted lower levels of radiation by accepting guidelines set by the International Commission on Non-Ionising Radiation Protection (ICNIRP). However, the ICNIRP standard does not offer any form of protection other than from the heating effects of microwave radiation. In other words ICNIRP only protects your body from properties of high levels of elevated temperatures. A very substantial body of peer reviewed scientific research clearly shows many biological changes have already occurred. In 2005, a group of German doctors in Bamberg, Oberfranken wrote an open letter to the German Prime ministry explaining the evaluated medical complaints of 356 people who have had long-term radiation exposure in their homes from pulsed high frequency magnetic fields (from mobile phone base stations, from cord-less telephones, amongst others).

Waldmann-Selsam and Saeger 2005 stated that people living close to a mobile phone base station suffer from one or several of the following symptoms like sleep disturbances, tiredness, disturbance in concentration, forgetfulness, problem with finding words, depressive mood, ear noises, sudden loss of hearing, hearing loss, giddiness, nose bleeds, visual disturbances, frequent infections, sinusitis, joint and limb pains, nerve and soft tissue pains, feeling of numbness, heart rhythm disturbances, increased blood pressure episodes, hormonal disturbances, night-time sweats, nausea. A 2002 survey study by Santini et al. in France found a variety of self-reported symptoms for people living within 300 meters of GSM cell towers in rural areas, or within $100 \mathrm{~m}$ of base stations in urban areas. It should be noted that the health related symptoms were most frequently reported at a distance of 50 to $100 \mathrm{~m}$, which fits perfectly to the area with the highest microwave 
exposure in urban areas, where the main beam of the antennas usually hits the first houses. Fatigue, headache, sleep disruption and loss of memory were among the symptoms reported. Similar results have been obtained with GSM cell towers in Spain, Egypt, Poland and Austria. A second study carried out in Austria showed significant positive associations between the frequency selective measured electric field (GSM 900/1800) in the bedroom and cardiovascular symptoms (Santini et al, 2002).

There are however, significant challenges in conducting studies of populations near base stations, especially in the assessment of individual exposure. In many countries, most notably the US, Australia and New Zealand, the governments have all taken this issue sufficiently seriously at both national and local levels. This has led to an adoption of precautionary principles and introduction of policies of prudent avoidance which have effectively banned the erection of these masts from school buildings and residential areas and in other densely populated locations. The effects upon human health by exposure to electromagnetic radiation, from a biochemical view point, would appear to show ill health is caused by the displacement of electrolytes/ions within the body and by interfering with the body's natural way of communicating (neurological system) and maintaining homeostasis - balance. This weakens the defense mechanism of the body as the body expends energy attempting to redress this imbalance. We cannot get away from these electromagnetic fields because we live within their field of influence, the body will be unable to correct this electrical and biochemical imbalance. And as the science of Biophysics has proven that we only become ill when the defense mechanism of the body is weakened, it follows that we will undoubtedly become ill as a direct result of living or working within these electromagnetic fields. Dr David Carpenter, Dean of the State of New York School of Public Health in 1995 having been convinced that EMFs pose a health hazard, concluded there is statistical association between magnetic fields and cancer that goes beyond the shadow of reasonable doubt - "I think there is clear evidence that exposure to EMFs increases the risk of cancer". This is most clear with leukaemia and brain tumours. However, in residential studies, statistical significance increased for all kinds of cancers. A whole body of evidence that reproductive cancers are increased by exposure is beginning to evolve. With such conviction and realization of the health implications, President Bill Clinton in the USA, issued a formal memorandum in 1995, stating that Transmitter Masts should not be sited on schools or near residential areas. Also a German study found a threefold higher frequency of cancer among people living in the vicinity $400 \mathrm{~m}$ of a GSM base station compared to people living further away from the antenna. The frequency increased also the longer people had been exposed to the radiation (Eger et al, 2004).

Sometime in 2004, a Nigerian Professor by name Bola Osijo, Chairman of the Nigeria Nuclear Medical Council, warned that the erection of telecoms masts in residential areas was capable of causing cancer and other chronic diseases. She disclosed that about 50,000 Nigerians were being infected with cancer yearly before the advent of the telecommunications masts, and reiterated that the influx of the masts into the telecommunications industry and their erection in residential areas, had the propensity to increase cases of the cancer disease. She added a warning that should nothing be done to prevent indiscriminate citing of telecoms masts, more Nigerians will be afflicted with the scourge. She had stressed then that research carried out by her committee had come up with findings that masts emit radiation that are dangerous to human health and could easily result to cancer. She emphasized that the radiation from a source like the GSM masts affects human cells and in the long run result in cancer (Nkanga, 2007). This study is aimed at investigating the potential risk of Base Transceiver Stations (BTS), otherwise known as communication masts on human health.

\subsection{Objectives}

The specific objectives of this study are to;

a) Identify and take inventory of the spatial distribution and pattern of BTS in the study area.

b) Analyze the health hazards associated with the existing location of BTS.

c) Identify possible areas at risk to electromagnetic radiation from BTS.

d) Map out areas vulnerable to the health hazards related to electromagnetic radiation from BTS.

e) Suggest and make recommendation to avoid risky money making health hazard.

\subsection{Limitations of the Study}

The study is strictly demonstrating how the Nigerian Earth Observation Satellite (NigeraSat-2) can be used to identify residential areas, schools and even hospitals that are vulnerable to possible electromagnetic radiation and thermal heating from Base transceivers station (BTS) but not the medical aspect. And again, this study is not measuring and quantifying the amount of radiation from Base Transceivers Station (BTS).

\subsection{Justification of the study}

Health is wealth - a popular saying. People living close and around a communication mast are regarded as vulnerable to Electromagnetic Radiation (EMR). Such people are susceptible to various chronic health hazards emanating from the radiation. The effects of EMR are usually not limited to humans within the radiation 
emission area but also the different biodiversity and the environment as a whole. In recent times, the sale of spaces in residential and play grounds for the erection of BTS has become rampant in Nigeria generally. Telecommunication companies take advantage of the poverty level in the country by enticing resident owners with huge sum of money to give up part of their land for the erection of BTS in the compounds knowing the health implication. The health hazards from such erections raise serious concern as electromagnetic radio frequency signals emitted by these mobile phone towers (BTS) are linked to ill health and health deficiencies such as fatigue, headache, decreased concentration, dizziness, local irritation, tumour induction, sperm motility, morphology and viability, cancer, especially brain tumour and leukaemia, viral and infectious diseases among the people who live near the BTS.

The Nigerian Regulatory Agency responsible for the enforcement and regulation of such radiation standards, National Environmental Standards and Regulation Enforcement Agency (NESREA) appears not to be living up to its billing. Hence, there is need for this research so that we can protect our citizens from untimely deaths and build a sustainable future together with utmost consideration for the environment as well.

\subsection{Study Area}

Federal Capital Territory (FCT) is the home of Abuja, the capital of Nigeria. The territory was formed in 1976 from parts of former Nasarawa, Niger, and Kogi States and it is in the central region of Nigeria, bordered to the north by Kaduna State, to the east by Nassarawa State, to the south-west by Kogi State and to the west by Niger State. It lies between longitudes $6^{0} 20^{\prime} \mathrm{E}$ and $7^{\circ} 33^{\prime} \mathrm{E}$ of the Greenwich Meridian and with latitudes $8^{0} 30^{\prime} \mathrm{N}$ and $9^{0} 20^{\prime} \mathrm{N}$ of the equator. It occupies an area of about $8000 \mathrm{~km}^{2}$. The FCT is located in the centre of the country in the guinea savannah of the middle belt. The geological formation of the FCT is basically basement complex formation and the soil structure of the area is thin with texture generally stony to gravelly sand with smaller occurrence of loam. Abuja in the FCT has two distinct seasons, namely the rainy season that begins around March and runs through October and the dry season which begins from October and ends in March. However, within these seasons is a brief harmattan season that is occasioned by the north east trade wind and the attendant dust haze, increased cold and dryness. Rainfall in the FCT reflects the territory's location on the windward side of the Jos Plateau while the monthly rainfall distribution intensifies during the months of July, August and September. The annual average rainfall of the FCT is $1221.2 \mathrm{~mm}$.

The largest indigenous group in Abuja are the Gbabyi (also known as the Gwari). The next largest indigenous group are the Koro. Smaller indigineous groups also inhabit the area, such as the Gade, Egbura, Gwandara, Bassa and the Gana gana. Being centrally located, Abuja is blessed with a mix of agricultural produce such as tubers and root crops of the south (yams, cassava, maize and plantains) and grain (sorghum, guinea corn and rice) of the north. The FCT has proven deposits of a wide range of mineral resources including marble, tin, mica, clay, wolfromite, tantalite and talc.

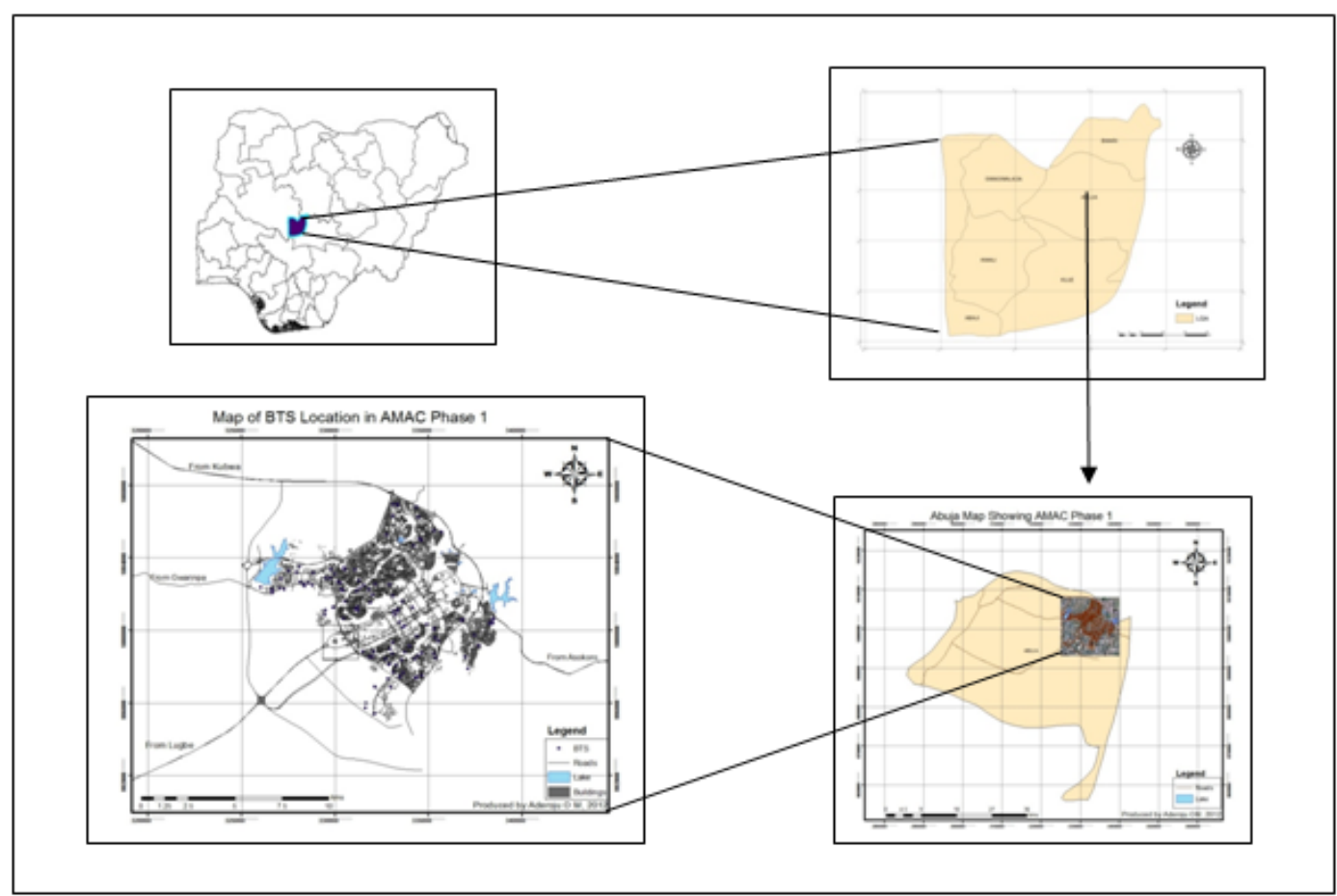

Fig 1.0: Abuja Municipal Area Council (AMAC) Phase1, FCT 


\section{Literature Review}

\subsection{Review of Global Standards on the siting of Base Transceiver Stations.}

Health Canada's Safety Code 6, 2008 issued a guideline based on Thermal Heating and possible radiation, whereas some experts point to biological effects such that there is the stress factor of having masts to close to homes and schools. This guideline shows the appreciable distance that is allowed in locating a GSM mast to homes and schools.

\begin{tabular}{|l|l|l|}
\hline Mast Height $(\mathrm{m})$ & At Ground Level & First Floor Window (7.5m high) \\
\hline $15 \mathrm{~m}$ & $75-125 \mathrm{~m}$ & $30-80 \mathrm{~m}$ \\
\hline $30 \mathrm{~m}$ & $175-225 \mathrm{~m}$ & $100-175 \mathrm{~m}$ \\
\hline $45 \mathrm{~m}$ & $250-350 \mathrm{~m}$ & $150-250 \mathrm{~m}$ \\
\hline
\end{tabular}

Table 1.0: Criteria for siting a BTS

\subsection{Reviewed Study on Health implication of BTS in residential areas and schools.}

- Ronni and Danny in 2004 carried out a study based on medical records of the people living within $350 \mathrm{~m}$ of a long established phone mast, which showed a fourfold increase incidence of cancer compared with the general population of Israel especially among women.

- Santini et al,: Pathol Biol (Paris) in 2002 found significant effects on people living within $300 \mathrm{~m}$ of mobile phone base stations and it was advisable that mobile base stations not sited closer then $300 \mathrm{~m}$ to population.

- The New South Wales Minister for Education in 1997 stated "The Department of School Education objects to installation of mobile phone towers near schools, and that normally means within a radius of 500 meters. This objection is based on a policy of prudent avoidance". Since children spend more time at home than at school, it follows that this same prudent avoidance should apply to residential areas (Ash, 1995).

Based on literatures and other studies carried out, it is evident that possible health risk of residence / schools close to a Base Transceivers Station (BTS) are blurred vision, cancers, lung diseases, heart problem, headaches, migraine, nauseas, tumors, lesions, childhood leukemia, sleep disorders, physical disabilities, dizziness, miscarriage and many more.

a. Data Acquisition and Data Sources:

\section{Methodology}

The data used for this study were obtained from both primary and secondary sources. The primary sources involved the use of GPS receiver to obtain the coordinates of Base Transceivers Stations (BTS) in the study area and also personal interviews with station engineers of MTN and Etisalat, guards at the BTS locations and also some inhabitants around the identified BTS locations. The secondary data used is a high resolution satellite imagery of the NigeriaSat- 2 with resolutions $2.5 \mathrm{~m}$ and $5 \mathrm{~m}$ panchromatic and multispectral respectively. The imagery was obtained from the National Space Research and Development Agency (NASRDA), Abuja in 2013.

\section{b. Geo-database design and database creation}

Geo-database design was done based on the features of interest identified on the satellite imagery used. The identified features of interest were highway, minor roads and settlements. The database creation for the Base Transceiver's stations simply comprises of the followings; BTS coordinates (Northings and Eastings), Service provider's name, Residence type around the BTS location and Address of the BTS location.

\section{c. Field Work}

The study area was divided into districts to ensure accuracy and also avoid duplicating efforts.

I. The use of a Global Positioning Systems (GPS) to obtain coordinates on all the location of the BTS in the study area.

II. Personal interviews with the some MTN, GLO and Etisalat engineers, BTS guards and some inhabitants living around Base Transceivers Station in the study area to obtain information on the Base Transceivers Station itself.

\subsection{Laboratory analysis}

i. Data processing (Georeferencing and on screen digitizing): Georeferencing of the satellite image was required so as to bring them to the same ground coordinates. The georeferencing of the satellite image was done using the ArcGIS software. The coordinate system of the datasets was projected to WGS 1984, Universal Transverse Mercator, Datum 100 Minna - Nigeria, Zone $32^{\circ} \mathrm{N}$. The georeferencing was done with the selection of four $\mathrm{X}$ and $\mathrm{Y}$ coordinates tie points that are spatially distributed and points were added, and map was then rectified. GPS coordinates of BTS obtained during the field survey was plotted on the image. The creation of a personal geodatabase for each feature of interest was done in ArcCatalog extension of the ArcGIS 9.3. The digitizing process was done in the ArcMap environment for feature 
extraction. Digitizing is the process of converting geographical features from an analogue or raster map into vector format.

ii. Geospatial Analysis: The basic spatial analysis employed during this work was done using ArcGIS 9.3. Buffering operation was done at specific distance $10 \mathrm{~m}, 20 \mathrm{~m}, 50 \mathrm{~m}$ and $100 \mathrm{~m}$. This was created around the BTS in order to determine the proximity level to residential areas, schools, hospitals and many more. Proximity analysis was equally performed via query to know the closeness level of settlements to BTS.

\section{Results and Analysis}

The table 2.0 shows the location and the service providers of identified BTS in Abuja Municipal Area Council (AMAC), FCT. This also has information like the address of the location of the Base Station, residential type and also elevation of the point in which the BTS is located.

\begin{tabular}{|c|c|c|c|c|c|c|}
\hline & Northing: & Easting: & $\begin{array}{l}\text { Elaration } \\
\text { (m) }\end{array}$ & Sarties Proridar & $\begin{array}{l}\text { Rasidantial } \\
\text { Typa } \\
\end{array}$ & Adiress of BTS Location \\
\hline & & & & & & \\
\hline 1 & 333775 & 997311 & 517 & MTN \& VISAFONE & Madim & Pat 239 Enaza sanatGarici \\
\hline 2 & 333557 & 997650 & 517 & MTS & Madium & Modal grimasy school Garki 2 \\
\hline 3 & 333450 & 997478 & 515 & ETTSALAT & Madirm & Garki 2 polis HQ \\
\hline 4 & $33345^{7}$ & $99^{7} 432$ & 516 & GLOBAOOM & Madium & Garki 2 polies HQ \\
\hline 3 & 334273 & 997353 & 517 & GLOBACOM & Madium & 6 Sapala Srast basida NURTW,Garia \\
\hline 5 & 334372 & 997424 & 517 & MTN & Madium & NSpice cas Garki 2 \\
\hline 7 & 334525 & 997507 & 515 & MTS & Madium & Ladola Akintola bonlarard way Garki \\
\hline 5 & 335351 & 999494 & 517 & MTS & Madirm & ANDLA caxtar plaze Mohammaty Bhari way \\
\hline 9 & 333295 & 995724 & 516 & GLOBACOM & Madrum & So Oro Ago Srast \\
\hline 10 & 332516 & 997329 & 518 & MTS & Madirm & 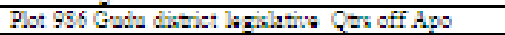 \\
\hline 11 & 332159 & 995565 & 524 & GLOBAOOM & Low & Dremiknil \\
\hline 12 & 332149 & 996573 & 326 & MITN & Low & Dremikill \\
\hline 13 & 332125 & 995599 & 525 & AIRTEL & Low & Dreminill \\
\hline 14 & 332119 & 995903 & 526 & VTSAFONE \& MULTI & Low & Dremikn \\
\hline 15 & 332116 & 995399 & 494 & GLOBACOM & Madium & Axon plazs 1055 gatu diknist \\
\hline 16 & 331617 & 995717 & 495 & MTN & High & S4 David Ejoor erasant Gratu \\
\hline 17 & 331609 & 995722 & 453 & ETTSALAT & $\mathrm{Hin}$ & S4 David Ejoor erasant Grotu \\
\hline 18 & 331639 & 995990 & 493 & GLOBAOOM & Higin & 195 Dremel 2 by woy sehool \\
\hline 19 & 332978 & 996568 & 494 & ETISALAT & High & 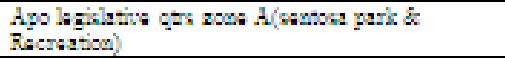 \\
\hline 20 & 335341 & 999532 & 520 & AIRTEL & Hing & 9 porthacout erasant Garici off gimbina sast \\
\hline 21 & 335349 & 999590 & 519 & GLOBACOM & Hin & 9 porthacout erasant Garki off ambing sast \\
\hline 22 & 335322 & 99,9424 & 323 & MTS & Hinis & 11 knowa stast off gimbina \\
\hline 23 & 331528 & 995355 & 455 & MTS & Hizin & Aras l, Fustion \\
\hline 24 & 331995 & 995351 & 452 & VTSAFONE & Hinin & Shatru saguro inglamis camtar \\
\hline 25 & 332944 & 995953 & 455 & MTS & Hinis & Along J.S Tarica Strast \\
\hline 26 & 333049 & 995709 & 491 & MTN & Low & Sholus shagaro isalamis castar \\
\hline 27 & 332694 & 995429 & 456 & MTS & Low & Fars bank Aras 3 Garki \\
\hline 25 & 333974 & 999141 & 510 & ETI, MTN, VISA & Low & Mosgea Aras 3 Opposita Starling Bani: \\
\hline 29 & 334359 & 999577 & 311 & GLOBACOM & Low & 74 Emaka Amaxusu Srast \\
\hline 30 & 334144 & 1001273 & $\$ 25$ & VISAFONE & Low & FadaralMotaga Band: \\
\hline 31 & 333525 & 1001531 & 509 & MTS & Lors & TOFA Hows CBD \\
\hline 32 & 333053 & 1001912 & 500 & $\begin{array}{l}\text { ETI, MTN" } \\
\text { VTSA.MUTT }\end{array}$ & Fing & Terahim Abacha Esas: Wasa Zoos 4 \\
\hline 33 & 332900 & 1002530 & 510 & GLOBACOM & Hin & SPortsaid Srast \\
\hline 34 & 332140 & 1002554 & 497 & ETI, MTN, & Low & 1S Zizan:hor strast \\
\hline 35 & 331525 & 1002453 & 473 & $\begin{array}{l}\text { ETI, NTN, } \\
\text { VTSA.MTLT }\end{array}$ & Low & Accra park Zona S \\
\hline 35 & 331315 & 1002345 & 471 & MTS & Low & Acera park Zoas 5 \\
\hline 37 & 331140 & 1002174 & 472 & AIRTEL & Low & 37 Khartoru stast Zons! \\
\hline 39 & 331199 & 1001305 & 453 & GLOBACOM & Hizin & Orana: agron Zous 2 \\
\hline 39 & 331797 & 1002255 & 459 & ETI & $\mathrm{Hin}=$ & Fas sertise statisn Zono 3 \\
\hline 40 & 332000 & 1001953 & 492 & ETI & Hinis & 7 itimbe szost weas zons 3 \\
\hline 41 & 331995 & 1001541 & 452 & MTN & $\mathrm{Hi}=\mathrm{h}$ & 23 Abidian szastwass zons 3 \\
\hline 42 & 331273 & 1002730 & 474 & GLOBACOM & Hin & Pot 2B Herbart Mareulay wose zous 5 \\
\hline 43 & 330455 & $10034^{71}$ & 513 & MTN & Hizin & Unity Park wase zone 5 \\
\hline 44 & 330505 & 1003352 & 495 & ETBALAT MUTTLNGS & Hinin & SNyale szast wowe zons 6 \\
\hline 45 & 331052 & 1003352 & 493 & MTS & Hizh & Cotsura crowesnt chinox gasst in zons 6 \\
\hline 45 & 329953 & 1003119 & 450 & GLOBAOOM & Hizin & 23 Yaorudi szast zona 6 \\
\hline 47 & 330164 & 1002655 & 473 & STARCOMUGATEWAY & Hi: $=$ & Total fling sation zons 6 \\
\hline 45 & 330259 & 1002514 & 473 & AIRTEL & Hizin & Caickan raproble zona 6 \\
\hline 49 & 330420 & 1002159 & 475 & GLOBAOOM & Hin: & Cogpar horas Zosa S \\
\hline 50 & 330323 & 1002249 & 451 & MTS & Hinin & Opp Coppar hous, Zoma S \\
\hline 51 & 330535 & 1001591 & 452 & MTS & Hin & 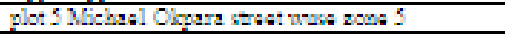 \\
\hline 32 & 330443 & 1000545 & 453 & GLOBACOM & Hinin & 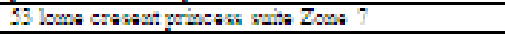 \\
\hline 53 & 331219 & 1001059 & 453 & MTN & Hin & Amosamant park zona 1 \\
\hline 54 & 331052 & 1001199 & 499 & 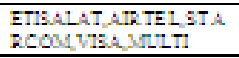 & Hizh & Amanomant park zona 1 \\
\hline$S S$ & 329320 & 1002553 & 477 & AIRTEL & Higin & Mosas majalosimami sa, Goldan astoria hotalUtalos \\
\hline 55 & 329743 & 1002553 & 475 & ETTSALAT & Hizh & 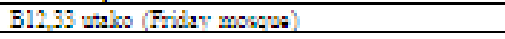 \\
\hline
\end{tabular}


Space-Based Assessment of the Compliance of Gsm Operators in Establishing Base ....

\begin{tabular}{|c|c|c|c|c|c|c|}
\hline 57 & 329756 & 1003377 & 473 & MTN & Hing & 2. Bucar Dipcharma sz, Tasion O olias Uako \\
\hline 58 & $325: 45$ & 1003155 & 460 & MTN & Hing & 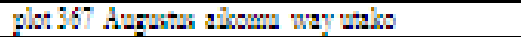 \\
\hline 39 & 327932 & 1003159 & 450 & AIRTEL & Hish & plot224 solomsola way utako, Coide hots. \\
\hline 60 & 323119 & 1003522 & 444 & MTN & Low & Bahind NHIS offise ualos Dinzist \\
\hline 61 & 325122 & 1002652 & 443 & 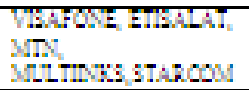 & Hizh & Oppokta jabi park uako \\
\hline 62 & 325354 & 1002429 & 450 & Po:om & Hivis & 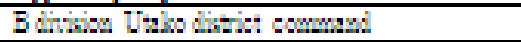 \\
\hline 63 & 325333 & 1002560 & 430 & MTN & Hian & 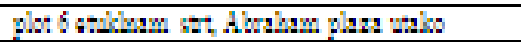 \\
\hline 64 & 325731 & 1002502 & 455 & MTN & His: & 297 olvotio abo Cresazt \\
\hline 63 & 325379 & 1002605 & 460 & AUTEL MUTHNOS & Hing & 26 A E Enacinam Srast Uahe. \\
\hline 65 & 326519 & 1002251 & 433 & MTN & Hing & 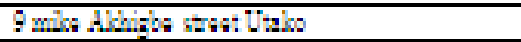 \\
\hline 57 & 325545 & 1002209 & 457 & MTN, MULTILNGS & Hing & IEmmarosi Adisla sz uabo. \\
\hline 65 & 325532 & 1002049 & $4 \leqq 3$ & GLOBAOOM & High & Pat 693 obsfam awolonv way zos B4 Utako \\
\hline 69 & 326030 & $100235^{7}$ & $44^{7}$ & AIRTEL & High & Rithard Akizids sast \\
\hline 70 & 327037 & 1002323 & 458 & ETISALAT & Hin & 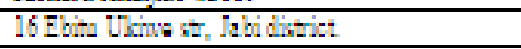 \\
\hline 71 & 327095 & 1002535 & 457 & MTN & Hish & 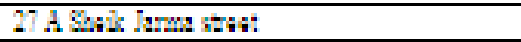 \\
\hline 72 & 327323 & 1003257 & 464 & MTN & Hing & 9. didsun Chroma crasat \\
\hline 73 & 327297 & 1002270 & 451 & MTN & Hi:in & Bs:C2 risma astat: \\
\hline 74 & $329 \% 18$ & 1001271 & 435 & $\begin{array}{l}\text { VBAFONE ETLALAT, } \\
\text { MNX MULTMNHS }\end{array}$ & High & Wus \\
\hline 73 & $329 \% 23$ & 1001293 & 453 & GLOBACOM & Hivis & Wuverstisu \\
\hline 76 & 329995 & 1001250 & 435 & ARTEL & Hing & Weveratisn \\
\hline 77 & 329495 & 1001120 & 432 & AIRTEL & High & plot 111 Pasea Hasua Wea \\
\hline 78 & 329454 & 1000579 & 499 & MTN & High & Cascara Srast Wor plot 674 \\
\hline 79 & 333124 & 997678 & 505 & Unicasux & High & CBN quanss \\
\hline 50 & 333251 & $99: 074$ & 503 & AIRTEL & High & 1Q Acadam sabool bayin labbi crosast \\
\hline 81 & $333: 45$ & 993351 & 305 & Unicarux & High & On wp of horat 6N1SE clow wast \\
\hline 52 & 332916 & 995155 & 505 & Uxisoru: & High & 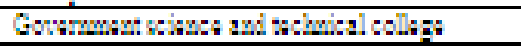 \\
\hline 83 & $3325^{7} 4$ & 995055 & 307 & MTS & High & 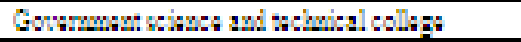 \\
\hline$\$ 4$ & 334265 & 999431 & 305 & Unicorux & Hish & Pot 1350 Ahmach Balo way garki 2 \\
\hline 85 & 334426 & 995601 & 512 & MULTLINR & Hing & Oxxio flling satisu garki 2 \\
\hline 85 & 334530 & 99574 & 505 & MTN & Hi: & Incide garki suparmarkat \\
\hline 57 & 333716 & 995502 & 499 & GLOBAOOM & High & Hora 2 Elat clos Garki \\
\hline 53 & 333991 & 999127 & 509 & GLOBACOM & Low & 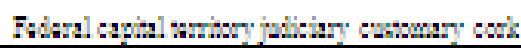 \\
\hline 99 & 334363 & 999652 & $\$ 17$ & GLOBACOM & Low & 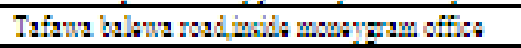 \\
\hline 90 & 334904 & 1000320 & 519 & MTN & Madim & Ixsida NTA basd geartars \\
\hline 91 & 335250 & 1000126 & 325 & Unionory & High & Aras 2Dinzist \\
\hline 92 & 335251 & 1000075 & 529 & Uxicarux & Low & Manaslphars Arasll garki \\
\hline 93 & 337092 & 997902 & 565 & MTN & Low & Daza bray sz,Nas AIT offes, Asoibaro \\
\hline 94 & 336954 & $995: 42$ & 571 & MTS & Low & Fatsos fatai wilim Srast, Anolsoro \\
\hline 99 & 337674 & 999157 & 537 & Unicarux & Low & Mamman Nasz Stant, Anoboro. \\
\hline 95 & 337457 & 999739 & $\$ 45$ & Ars: & Low & 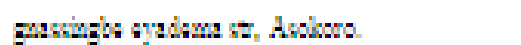 \\
\hline 97 & 339443 & 1000395 & 600 & GLOBAOOM & Low & By polise satisu asolsono \\
\hline 93 & 339407 & 1000563 & 590 & GLOBACOM & Low & By polses satson asolsoro \\
\hline 99 & 339459 & 1000545 & 550 & MTN & Low & By polise sation anoloro \\
\hline 100 & 335276 & 1000425 & $\$ 57$ & MTN & Low & Hailo sahaskis stast asoboro \\
\hline 101 & 335309 & 1000350 & 573 & GLOBAOOM & Low & Haila salaski sast: anoboro \\
\hline 102 & 336523 & 1000500 & 323 & G call & Low & plot 394, JF kansady sasat Anoloro \\
\hline 103 & 336763 & 1000573 & 534 & MTS & Low & plot 394, JF kansach saset Anoiburo \\
\hline 104 & 331455 & 995321 & 501 & Unionora & Low & Afrisan safaribotallenad aral \\
\hline 105 & 332049 & $995: 23$ & 494 & ETISALAT & Low & Dommac plazs Aras! \\
\hline 105 & 333052 & 999341 & 491 & Unionorn & Hish & $\begin{array}{l}\text { Nembar 4, borso szaton top of a two story } \\
\text { bulding aras10,Garki }\end{array}$ \\
\hline 107 & 333605 & 1000199 & 505 & ETHSALAT & Low & Cost to chalas hotal \\
\hline 105 & 333743 & 1000249 & 304 & Unisorux & Low & Axasx mazophaze \\
\hline 109 & 333423 & 1000445 & 493 & Unicaron & Low & Ahmady coomasia bous \\
\hline 110 & 333211 & 1000543 & 495 & Unisorux & Low & Bahizd niren plazs \\
\hline 111 & 333115 & 1001014 & 493 & Unimorna & Low & IGI cantral aras \\
\hline
\end{tabular}


Space-Based Assessment of the Compliance of Gsm Operators in Establishing Base ....

\begin{tabular}{|c|c|c|c|c|c|c|}
\hline 112 & 333345 & 1001139 & 501 & Uniongran & Low & Ixcida total office cartal aras \\
\hline 113 & 333352 & 1001045 & 315 & Unionoran & Low & Bahiad wal bulding A jo bulding carral Aras \\
\hline 114 & 333054 & 1005953 & 320 & Unionorn & Low & Torahim babungida way Natama \\
\hline 115 & 333320 & 1005950 & 570 & MUTTILAR & High & Toxnase crassut Watama \\
\hline 116 & 333350 & 1005579 & 567 & Unicaonan & Low & Torahim babaxaida boolongard, Matama \\
\hline 117 & 334351 & 1005503 & $\$ s 3$ & Unionorax & Low & Opposta Ssmerng bulding Natame Mapa fortion \\
\hline 118 & 334343 & 1005310 & 549 & MTS & Low & Mogpa jastion \\
\hline 119 & 335292 & 1005323 & $\$ 14$ & GLOBACOM & High & Ixkide modsl primary sahool Matama \\
\hline 120 & 335553 & 1005433 & 501 & MTN axd AIRTEL & Low & Opposta Paliginas ambassy, Majama \\
\hline 121 & 334473 & 1005257 & 549 & MTS & High & Rime szat Watama \\
\hline 122 & 333051 & 1005292 & 520 & $\begin{array}{l}\text { MTNETTSALAT AND } \\
\text { STARCOM }\end{array}$ & Low & Ahan ùsolsu way, Matama \\
\hline 123 & 332733 & 1005279 & 321 & MTSN & High & African Safaribotalmalong szost Matama \\
\hline 124 & 334214 & $10045^{74}$ & 521 & MULTILR & High & 2507 maxi ostats, off britich cormal Matama \\
\hline 125 & 334532 & 1005059 & 532 & AIRTEL & High & Salam gasst bouk, Matama \\
\hline 126 & 334523 & 1004951 & 498 & MTN & High & 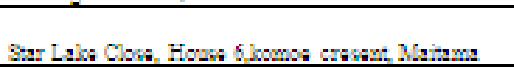 \\
\hline
\end{tabular}

The figure 2.0 shows the spatial distribution of BTS in AMAC environs.

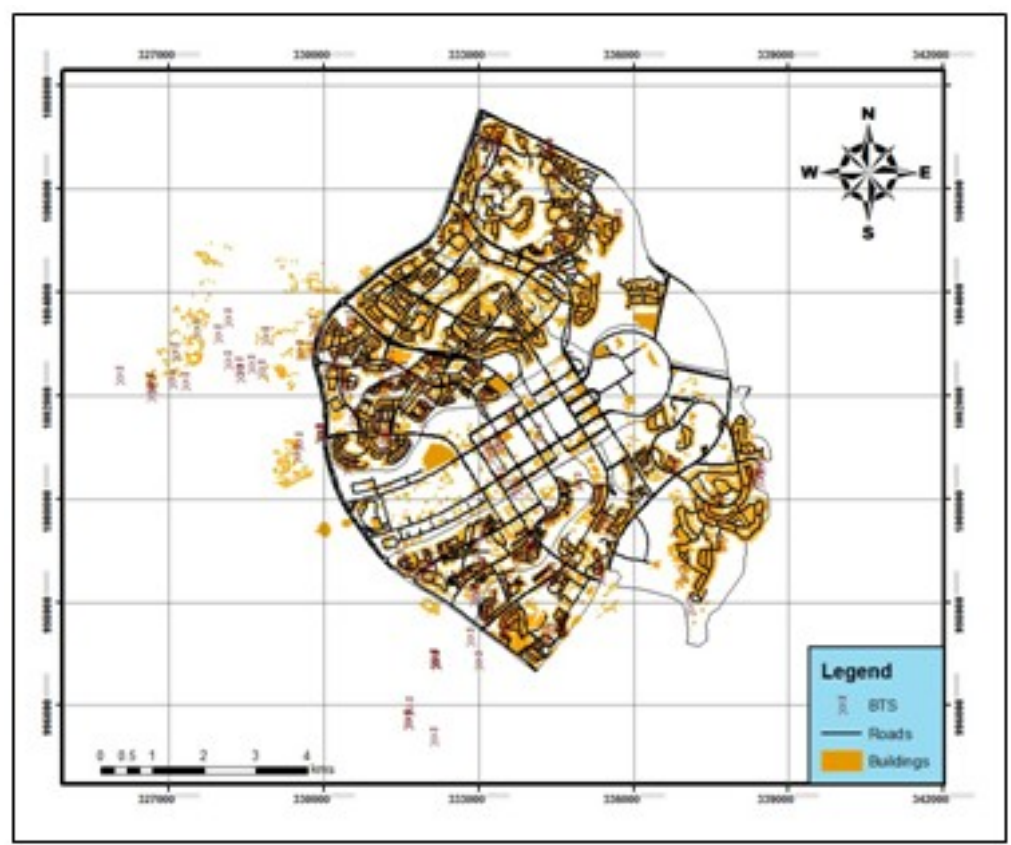

\subsection{Existing Standards and Regulations on the siting of Base Transceiver Station in Nigeria}

NCC guidelines of 2009 on the installation of telecommunications mast and towers state as follows;

- Telecommunications tower above $25 \mathrm{~m}$ in height would not be permitted with districts delineated as residential.

- Where tower in excess of $25 \mathrm{~m}$ in height are permitted, they should be placed at minimum setback of $5 \mathrm{~m}$ distance to the nearest dismissed property, excluding the fence.

But in 2011, National Environmental Standards and Regulatory Enforcement Agency (NESREA) Abuja issued out a regulation in the National Environmental (Standards for Telecommunications and broadcasting Facilities) Regulations, 2011). This states that,

In respect to the Guidelines on Technical Specifications for the Installation of Telecommunications Masts and Towers issued by the Nigerian Communication Commission (NCC) and relevant guidelines by the National Broadcasting Commission (NBC), and the National Environmental Standards and Regulations Enforcement Agency (Establishment) Act, (2007) (NESREA Act, 2007) on the siting of BTS, the following guidelines should be adhered to;

- $\quad$ BTS must have a minimum setback of ten (10) meters from the perimeter wall (fence) of residential/business premises, schools and hospitals to the base of the mast/tower; and

- Where there is no perimeter wall (fence), a BTS must be at a minimum of twelve (12) meters from the wall of residential/business premises schools and hospitals to the base of the mast/tower.

- Telecommunications towers above 25 meters in height would not be permitted within districts delineated as residential. 
(Source: National Environmental (Standards for Telecommunications and Broadcasting Facilities) Regulations, 2011)

With these research carried out by various scientist from various countries, it has shown that the NCC, ICNIRP, WHO among others claims that radio waves from BTS have no health implications on human has to be looked into because people cannot continue to cope with what is detrimental to their health all in the name of technology and a wider coverage or reception. And again the NCC guideline and NESREA regulations did not take into account the Specific Absorption Rate (SAR) living organism beside BTS can attain before it is called detrimental to the body. No safe limit standards were put in place to actually check the radiation level in the living organism around BTS locations.

\subsection{Geospatial and Statistical Analysis}

The buffering of $10 \mathrm{~m}, 20 \mathrm{~m}, 50 \mathrm{~m}$ and $100 \mathrm{~m}$ was done around the Base Transceivers Stations (BTS) to be able to run a proximity analysis to BTS in the environs. Figures 3.0, 5.0, 7.0 show the buffered zones around BTS in Utako/Jabi, Wuse and Garki Districts.
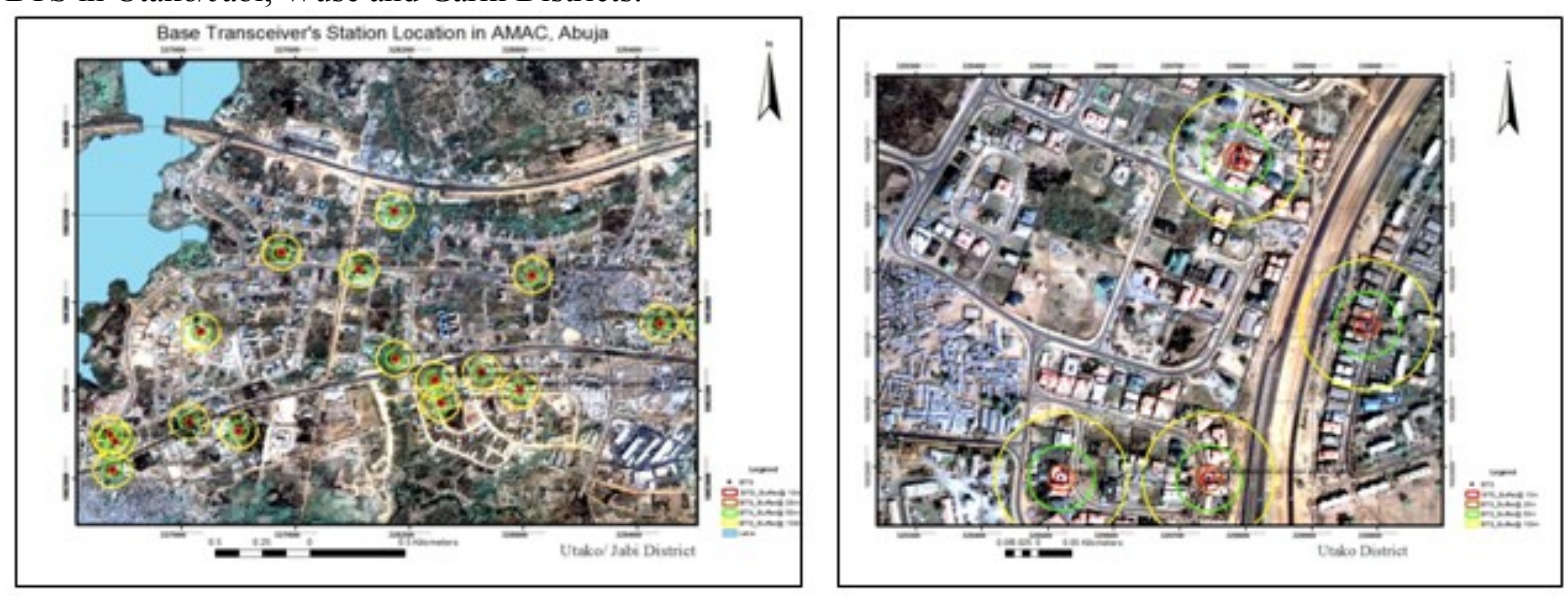

\section{Utako/ Jabi District}

15 Base Transceivers Stations (BTS) are available in Utako district.

1 BTS falls within the low residential area of Utako district.

14 BTS falls within the high residential area of Utako district.

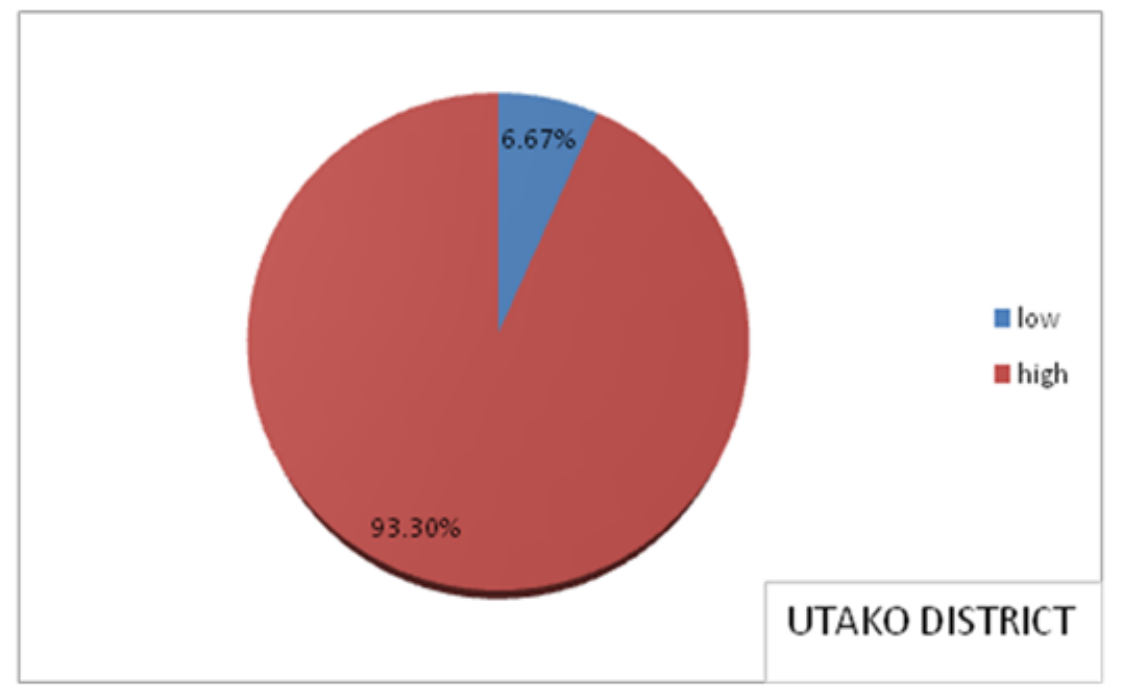

Fig 4: BTS \% representation of Utako/ Jabi District

From the statistical analysis, $93.3 \%$ of the Base Transceivers Stations (BTS) available in the Utako district falls within the high residential area while $6.67 \%$ of the BTS falls within the low residential area of the Utako district. This shows many of the inhabitants living close to a BTS in Utako district are vulnerable to high risk of electromagnetic radiation from a BTS. 

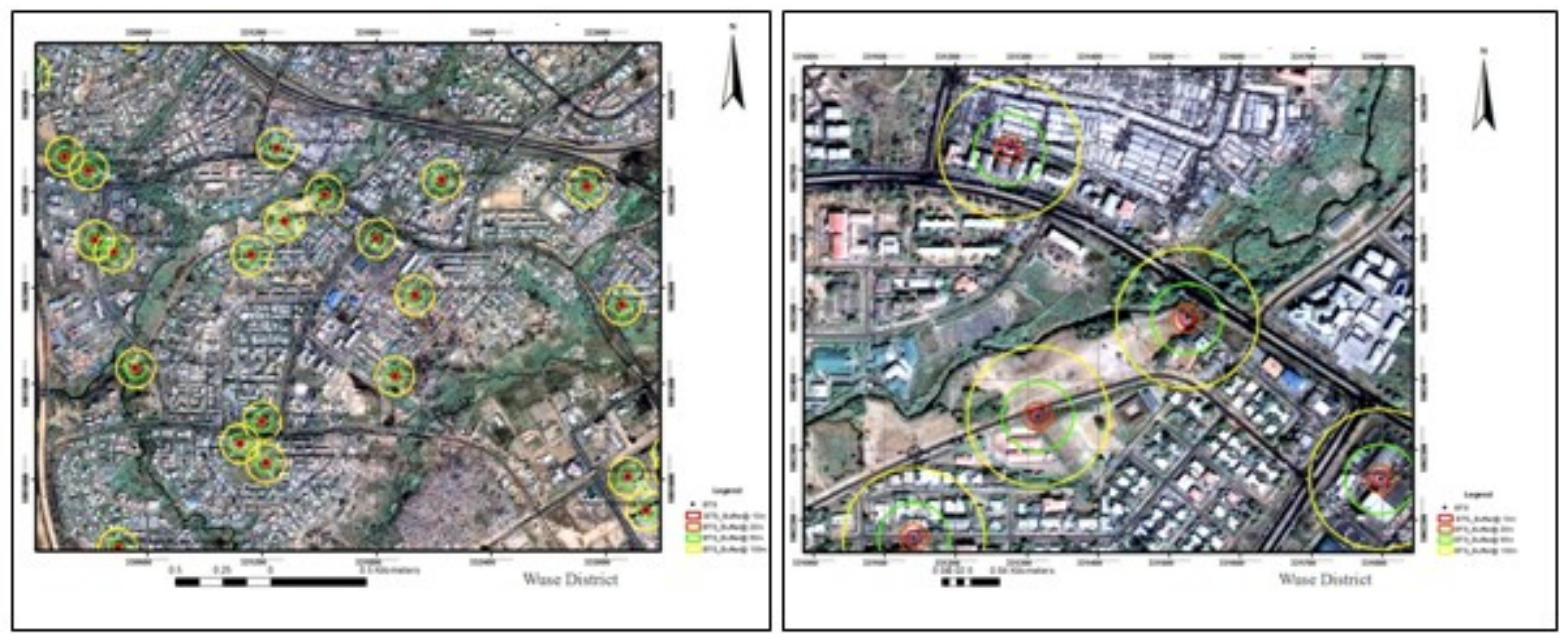

Fig: 5.0. BTS in Wuse District and Vulnerable settlements

\section{Wuse District}

29 Base Transceivers Stations are available in the whole of Wuse district.

4 BTS fall within the low residential area of Wuse district while 25 BTS fall within the high residential area of Wuse district.

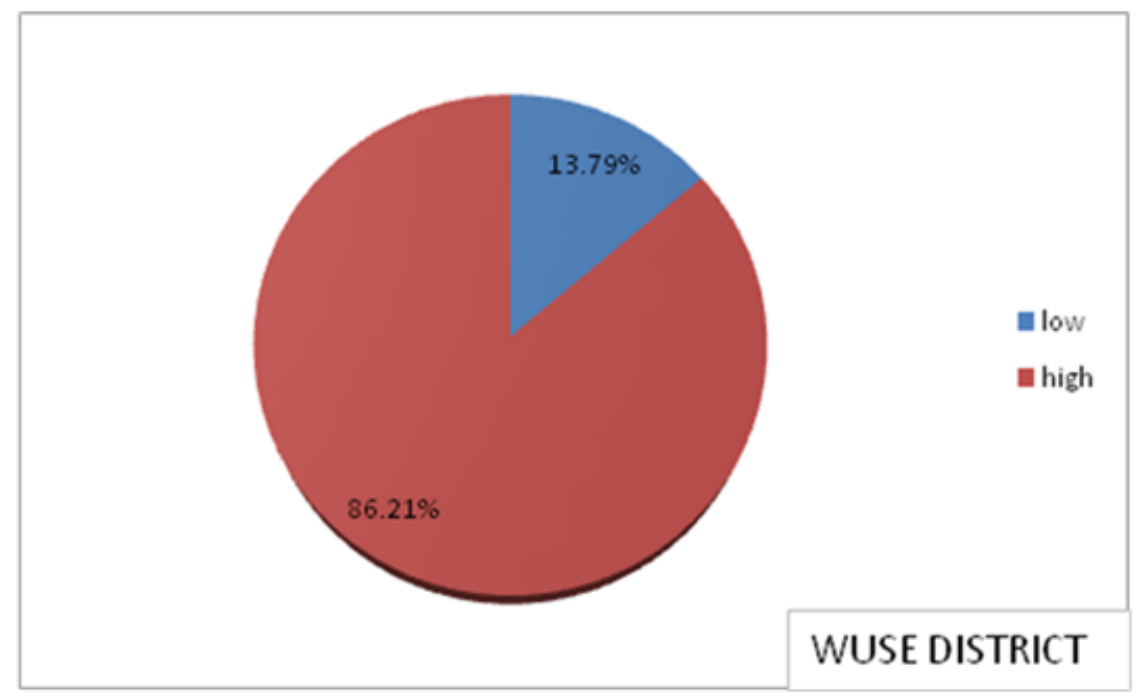

Fig 6.0: BTS \% representation of Wuse District

From the statistical analysis, $86.21 \%$ of Base Transceivers Stations (BTS) available in Wuse district (Zones 1, 2, 3,4,5,6 \&7) falls within the high residential area of the district while $13.79 \%$ of BTS falls within low residential location of Wuse district. This shows many of the inhabitants living close to a BTS in Wuse district are vulnerable to high risk of electromagnetic radiation from a BTS. 

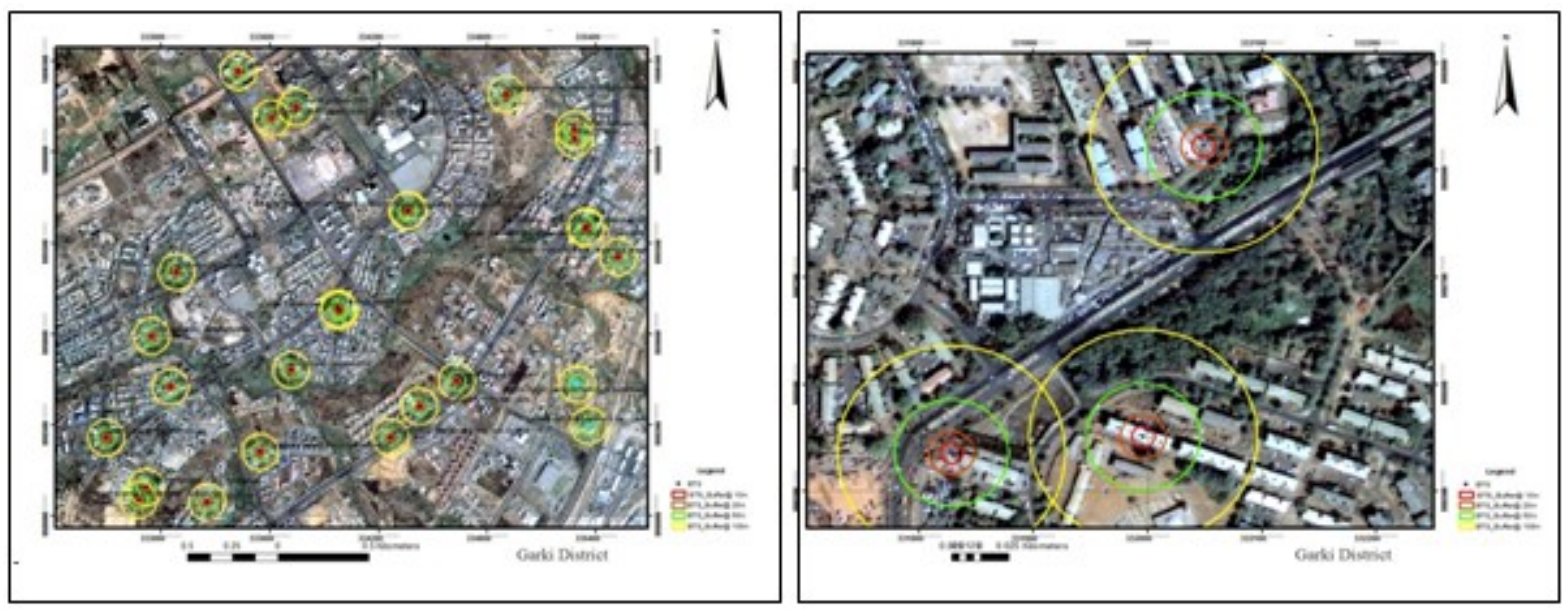

\section{Garki District}

\section{BTS are available}

- 10 BTS falls within the in low residential area

- 11 BTS falls within the in medium residential area

- 10 BTS falls within the in high residential area

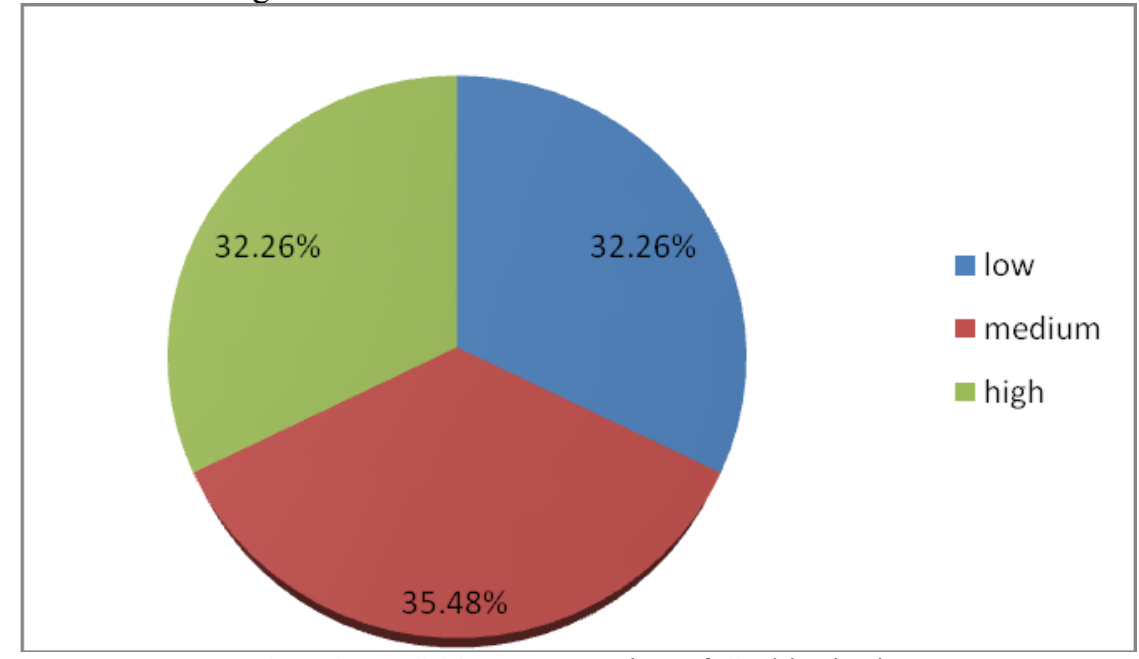

Fig 7.0: BTS \% representation of Garki District

- Low residential location of BTS, $32.26 \%$ is within the Garki district

- Medium residential location of BTS, $35.48 \%$ is within the Garki district

- $32.26 \%$ of BTS available in Garki district falls within the highly residential area.

It shows that the inhabitants of this location are vulnerable to high risk of electromagnetic radiation from a BTS. 


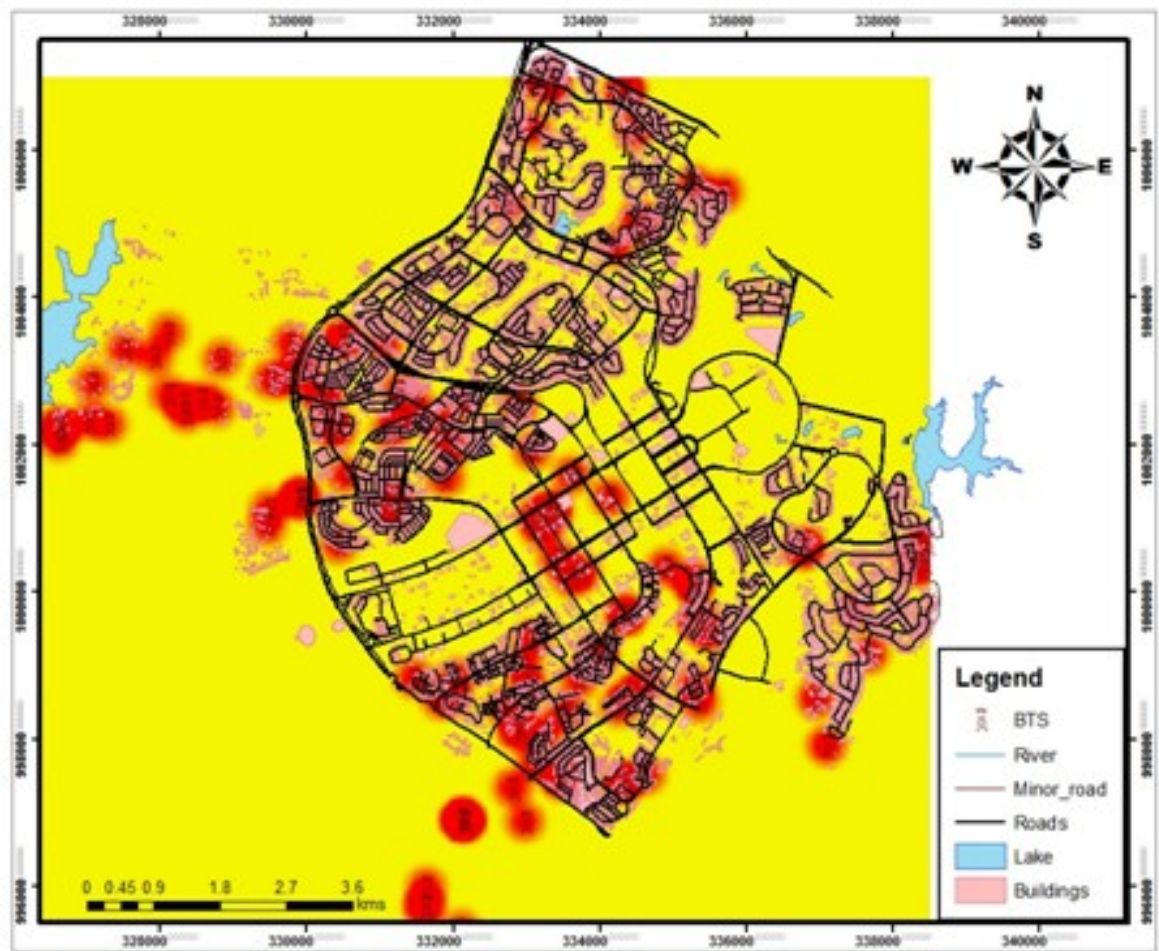

Fig 8.0: Settlement Risk Map in BTS location

\section{Discussion}

Based on the available guidelines, in Nigeria by NCC \& NESREA, this simply states that no communication mast should exceed $25 \mathrm{~m}$ height and at distances of $5 \mathrm{~m}$ (NCC), 10m (NESREA) from a fence and $12 \mathrm{~m}$ (NESREA) in areas with no fence. This has clearly shown that the residence that within distances $10 \mathrm{~m}$ to $20 \mathrm{~m}$ are vulnerable to electromagnetic radiation emitting from the Base transceivers stations BTS in the entire district going by the NESREA regulations. But in a broader view whereby some researchers went as far as a distance of $400 \mathrm{~m}$ radius is a safe for siting BTS to homes, schools and hospitals, we have decided to at least create a radius of maximum $100 \mathrm{~m}$ radius from a BTS to homes, schools and hospitals. The figure 8.0 is simply a map showing settlement at risk with respect to radiation from BTS using the NESREA standards of $10 \mathrm{~m}$. It has been deduced from the geospatial analysis that most service providers violate the standards issues by NESREA which makes the inhabitants around BTS at high health risk. This is still not enough according to researches carried out in developed countries and various types of complain of carcinogenic diseases, issues of miscarriages, necessary and many more as mentioned above was researched into. The buffer zones created around the identified BTS at $10 \mathrm{~m}, 20 \mathrm{~m}, 50 \mathrm{~m}$, and $100 \mathrm{~m}$ is way below the distances of BTS to residential area causing health hazard in developed countries according to some researches. This study has simply shown that at the created buffer zones to check the proximity of residential areas, school and hospitals, which simply means that at $10 \mathrm{~m}$, which is the identified standard by NESREA, this BTS location still violets the max distance. Again viewing it from the ravened research point of view, $100 \mathrm{~m}$ distance is even at risk to residential areas, schools, and hospitals. It was concluded that by statistics that

- $35.48 \%$ of BTS falls within highly residential areas in the Garki district.

- $86.21 \%$ of BTS falls within highly residential areas in the Wuse district.

- $93.30 \%$ of BTS falls within highly residential areas in the Utako/ Jabi district.

\section{Conclusion}

In this study, geospatial techniques and statistics were integrated for mapping and analysis of Base Transceiver station (BTS) and also its risk to settlements around it. It was observed that out of the 126 BTS stations sampled in the AMAC phase 1,119 BTS sampled in the study failed the $10 \mathrm{~m}$ and $12 \mathrm{~m}$ buffer zone tests and only 7 BTS met the NESREA standards of $10 \mathrm{~m}$ and $12 \mathrm{~m}$ distance to residential areas, schools and hospitals. It was clear that the 7 BTS that met the NESREA standards were located on Durumi hills, Accra Park in Wuse, Zone 5 and on Ibrahim Babangida way, Booloyard, Maitama. All these BTS belong to MTN, Visafone, Etisalat, Multi-link, Globacom, and Airtel. 


\section{Recommendation}

There should be proper awareness on the possible health risk on people living close to a Base Transceivers Station (BTS). The regulatory agencies should keep checks on service providers that violate the $10 \mathrm{~m}$ and $12 \mathrm{~m}$ of siting BTS away from residential areas as stated in the NESREA regulations for telecommunication and broadcasting standards.

The regulatory agencies should also invest in R\&D in order to confirm all others studies and complains about electromagnetic radiation and thermal heat causing health problems so that a more reasonable buffer zone for BTS siting will be issued as a regulation to service providers.

\section{Acknowledgements}

Our appreciation goes to the National Space and development Agency (NASRDA), Abuja for facilitating and supporting this research with data (NigeriaSat 2 imagery and other logistics) that helped in the course of this research. We also use this opportunity to thank the Director of Strategic Space application, (NASRDA) Dr Halilu Shaba, and the head of Hazards and Environmental Management, Strategic Space application, (NASRDA) Dr Godstime James for mentoring and supporting us during this research.

\section{References}

[1]. Ash David (1995): The new Science of the Spirit, The College of Psychic Studies, London.

[2]. Eger H, Hagen H U, Lucas B, Vogel P, Voit H (2004): The Influence of being Physically near to a Cell Phone Transmission Mast on the Incidence of cancer, Published in Umwelt-Medizin. Gasellschaft 17, 4.

[3]. Health Canada Safety Code 6, 2008

[4]. Kwan-Hong N (2003): Radiation mobile Phones, Base Stations and Your Health, Published for Malaysia Communications and Multimedia Commission.

[5]. National Communication Commission Guidelines for the Installation of Telecommunications Mast and tower, 2009.

[6]. National Environmental Standards for Telecommunications and Broadcast Facilities Regulations, 2011, Federal Republic of Nigeria Official Gazette.

[7]. Nkanga E (2007): Are Base Stations Dangerous to Human Health?, (AllAfrican.com).

[8]. O'Connor E (2005): Trustee for the E M Radiation research Trust (www.radiationresearch.org)

[9]. Powerwatch: German Doctors Unite on RF health effects, July 2005. www.powerwatch.org.uk/news.

[10]. Ronni W, Danny W (2004): Increase incident of cancer near a cell-phone Transmitter station, International journal of Cancer Prevention, Vol 1, No 2

[11]. Santini R, Santini P, danze JM, Le Ruz P, Seigne M (2002): Investigating on the health of people living near mobile telephone relay station. Pathol Bol (paris) 50 (6) : page 369-73

[12]. Waldmann-Selsam C, Saeger U (2005): Mobile Phone and Mast Radiation.

[13]. WHO, Cell phone and Brain Tumors, 15 reason for cancer, August 25, 2009. http://www.radiationreseearch .org/pdfs/reasons.a4.pdf. 